\title{
Analisis Faktor-Faktor yang Mempengaruhi Kepuasan Pelanggan Fixpay Menggunakan SEM dengan PLS
}

\author{
Antonius Yadi Kuntoro ${ }^{1}$, Moh. Arie Hasan ${ }^{2}$, Dedi Dwi Saputra ${ }^{3}$, Dwiza Riana ${ }^{4}$ \\ ${ }^{1}$ STMIK Nusa Mandiri \\ e-mail: antonius.aio@nusamandiri.ac.id \\ ${ }^{2}$ STMIK Nusa Mandiri \\ e-mail: hasan.arie@gmail.com \\ 3STMIK Nusa Mandiri \\ e-mail: sapoetrha.tkd@gmail.com \\ ${ }^{4}$ STMIK Nusa Mandiri \\ e-mail: dwiza@nusamandiri.ac.id
}

\begin{abstract}
Abstrak
Penelitian ini bertujuan untuk mengetahui pengaruh kualitas pelayanan, nilai pelanggan, dan kepercayaan terhadap kepuasan pelanggan pada Fixpay. Fixpay adalah sebuah platform Mobile Payment yang dapat melakukan beragam jenis pembayaran dan pembelian secara online dari smartphone..Penelitian ini menggunakan pendekatan kuantitatif dengan metode asosiatif. Data yang digunakan menggunakan data primer berupa kuesioner yang diperoleh melalui google form. Pengambilan sampel menggunakan teknik non random sampling sehingga diperoleh sampel penelitian sebanyak 100 responden. Hasil penelitian menunjukkan bahwa kualitas pelayanan, nilai pelanggan, dan kepercayaan berpengaruh signifikan terhadap kepuasan pelanggan Fixpay baik secara parsial maupun simultan. Disarankan kepada pihak perusahaan untuk terus meningkatkan kepuasan pelanggan, seperti dengan membuat mudah aplikasi Fixpay untuk dioperasionalisasikan, mudah mengakses aplikasi, dan meningkatkan nilai kegunaan dari aplikasi Fixpay. Pengolahan data dalam penelitian ini menggunakan Structural Equation Modeling (SEM) dengan Partial Least Square (PLS).
\end{abstract}

Kata kunci : Kualitas Pelayanan, Nilai Pelanggan, Kepercayaan, Kepuasan Pelanggan

\begin{abstract}
This study aims to determine the effect of service quality, customer value, and trust in customer satisfaction at Fixpay. Fixpay is a Mobile Payment platform that can make various types of payments and purchases online from smartphones. This study uses a quantitative approach with associative methods. Data used using primary data in the form of questionnaires obtained through google form. Sampling uses a non random sampling technique so that the research sample is 100 respondents. The results showed that service quality, customer value, and trust have a significant effect on Fixpay customer satisfaction both partially and simultaneously. It is recommended to the company to continue to improve customer satisfaction, such as by making it easy for the Fixpay application to be operationalized, easily accessing applications, and increasing the usability value of the Fixpay application. Processing data in this study using Structural Equation Modeling (SEM) with Partial Least Square (PLS).
\end{abstract}

Keywords: Service Quality, Customer Value, Trust, Customer Satisfaction

\section{Pendahuluan}

Perkembangan teknologi seluler di Indonesia meningkat signifikan. Menurut data yang bersumber dari Hootsuite, sebesar 120 juta pengguna atau sekitar $45 \%$ dari penduduk Indonesia adalah pengguna seluler yang aktif.
Peluang distribusi pulsa dan pembayaran elektonik lainnya ini juga semakin didukung dengan perkembangan teknologi informasi yang tandai dengan pertumbuhan internet di Indonesia. Menurut data yang diperoleh dari Asosiasi Penyelenggara Jasa Internet Indonesia (APJJI) bahwa penggunaan internet dari 
tahun ke tahun mengalami peningkatan sebesar 143,26 juta pada tahun 2017 dengan tren positif setiap tahunnya, seperti pada Gambar 1.

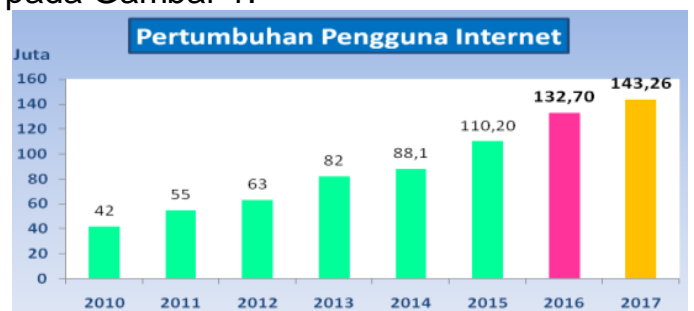

Sumber : Buletin APJII, 2018

\section{Gambar 1}

\section{Pengguna Seluler di Indonesia Tahun} 2018

Bisnis produk digital semakin menjadi tren karena meningkatnya pengguna seluler dan pengguna internet sebagai alat untuk melakukan pembayaran. Peluang tersebut dilirik oleh PT. Insan Hijrah Indonesia, yang mengembangkan sebuah platform pembayaran elektronik dengan nama produk Fixpay sebagai salah satu platform pembayaran elektronik untuk membantu masyarakat meningkatkan keuntungan bisnisnya. Fixpay menyediakan layanan pengisian pulsa, paket data, Listrik PLN (token dan tagihan), pembayaran BPJS Kesehatan, Cicilan, Telkom/Indihome dan PDAM yang dilakukan secara online dengan beragam metode pembayaran berupa Bank Transfer, Kartu Kredit dan Kartu Debit, Mandiri Virtual Account, BCA Virtual Account, Kredivo, dan Fixpay Kredit. Aplikas Fixpay dapat diunduh pada google play store dengan link https://bit.ly/fixpayid dan tampilan menu transaksi yang sangat mudah seperti pada Gambar 2 berikut ini.

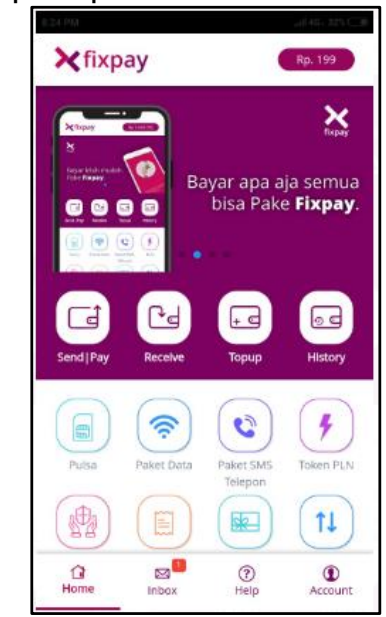

Gambar 2
Tampilan Menu Awal Fixpay
Kepuasan pelanggan menjadi konsep sentral dalam teori dan praktek pemasaran, serta merupakan esensial bagi aktivitas bisnis. Kepuasan pelanggan merupakan evaluasi purnabeli dimana alternatif yang dipilih sekurangnya sama atau melampaui harapan konsumen, sedangkan ketidakpuasan timbul bila hasil (outcome) tidak memenuhi harapan. Kepuasan konsumen dapat mempengaruhi persepsi dan selanjutnya memposisikan produk perusahaan dimata konsumen yang akhirnya akan membentuk loyalitas terhadap produk tersebut (Grace, 2017).

Di dalam penelitian tentang hubungan antara kualitas layanan Ecommerce dengan kepuasan, kepercayaan, dan loyalitas pelanggan menemukan bahwa kepuasan pelanggan dan kepercayaan pelanggan dipengaruhi oleh kualitas (Sobihah, Mutia., Mohamad, Mahadzirah., Ali, 2015). Penelitian lain mengungkapkan bahwa kualitas layanan, kepercayaan, dan teknologi seluler adalah faktor utama yang mempengaruhi kepuasan pelanggan dalam Mobile Commerce (Anh, 2015). Kepuasan yang lebih besar dikombinasikan dengan kepedulian yang lebih besar terhadap biaya pengalihan nonmoneter juga meningkatkan loyalitas pelanggan (Tsai, Tsai, \& Chang, 2010). Selanjutnya dalam penelitian lain ditemukan bahwa persepsi nilai pelanggan yang terdiri dari nilai kondisional dan nilai fungsional menunjukkan berpengaruh positif signifikan terhadap kepuasan pelanggan (Chen et al, 2017).

Penelitian ini fokus membahas Pengaruh kualitas pelayanan, nilai pelanggan, dan kepercayaan terhadap kepuasan pelanggan pada Fixpay. Permasalahan yang dapat dirumuskan pada penelitian ini adalah sebagai berikut:

1. Apakah kualitas pelayanan berpengaruh terhadap kepuasan pelanggan Fixpay?

2. Apakah nilai pelanggan berpengaruh terhadap kepuasan pelanggan FixPay?

3. Apakah kepercayaan berpengaruh terhadap kepuasan pelanggan Fixpay?

\subsection{Kualitas Pelayanan}

Kualitas layanan yang diakui oleh konsumen terdiri dari tiga dimensi yaitu dimensi fungsional, dimensi teknis dan citra perusahaan. Kualitas fungsional menjawab pertanyaan "bagaimana" layanan diberikan kepada pelanggannya, sementara kualitas teknis berfokus pada layanan "apa" yang 
disampaikan kepada pelanggannya. "Bagaimana" dapat disebut dalam hal kualitas proses, yang berarti evaluasi selama kinerja layanan, dan "apa" terkait dengan kualitas output, yang berarti evaluasi setelah kinerja layanan. Faktor ketiga, citra perusahaan dibentuk oleh kualitas teknis dan fungsional dan juga dipengaruhi oleh beberapa faktor eksternal, seperti komunikasi pemasaran, penetapan harga, dan kebutuhan pelanggan (Anh, 2015).

Kualitas layanan adalah memberikan kesempurnaan pelayanan yang dilakukan oleh penyedia layanan dalam memenuhi kebutuhan dan keinginan pelanggan serta ketepatan penyampaiannya untuk mengimbangi harapan pelanggan (Sembiring, Inka Janita., Suharyono., Kusumawati, 2010).

\subsection{Nilai Pelanggan}

Zeithaml mendefinisikan bahwa nilai pelanggan adalah penilaian menyeluruh tentang kegunaan suatu produk atau layanan berdasarkan persepsi tentang apa yang diterima dan apa yang dikorbankan (Mahaputra, 2017). Memberikan nilai pelanggan yang tinggi harus menjadi tujuan utama semua bisnis karena pelanggan membuat keputusan berdasarkan nilai yang mereka terima.

Sementara itu, Woodruff mendefinisikan nilai pelanggan sebagai preferensi persepsi dan evaluasi pelanggan terhadap atribut produk, kinerja atribut, dan konsekuensi yang berasal dari penggunaan produk yang memfasilitasi (atau menghambat) pencapaian tujuan dan sasaran pelanggan yang digunakan (Mahaputra, 2017).

\subsection{Kepercayaan}

Anh (2015) menjelaskan bahwa kepercayaan konsumen adalah faktor penting dalam adopsi m-commerce dan penting dalam membangun hubungan. Manfaat dari kepercayaan konsumen adalah bahwa ia membangun komitmen jangka panjang yang kuat dan jangka panjang bagi perusahaan. (Rehman, Shams Ur, Aamer Shareef, and A. Ishaque, 2012). Definisi kepercayaan adalah konstruk yang kompleks dan dapat sangat bervariasi dari berbagai perspektif, seperti: psikologi, ekonomi atau pemasaran, sosiologi dan segera (Lin, Wang, Wang, \& Lu, 2014).

Morgan dan Hunt (1994) dalam

Akbar dan Parvez (2009) menyatakan bahwa kepercayaan hanya terjadi ketika satu pihak memiliki keandalan dan integritas dalam suatu pertukaran. Sementara itu, jika satu pihak mempercayai pihak lain maka pada akhirnya melahirkan niat dan perilaku positif terhadap pihak kedua (Lau, G. \& Lee, 1999).

Namun, Mayer, Davis dan Schoorman (1995) dalam Anh (2015) memiliki definisi terintegrasi untuk kepercayaan sebagai kesediaan suatu pihak untuk menjadi rentan terhadap tindakan pihak lain berdasarkan pada harapan bahwa pihak lain akan melakukan tindakan tertentu yang penting bagi penggerebekan, terlepas dari kemampuan untuk mengendalikan bagian lain itu.

\subsection{Kepuasan Pelanggan}

Secara luas definisi tentang kepuasan terkait erat dengan harapan konsumen, dan secara lebih khusus, kepuasan diartikan sebagai semakin sempit perbedaan antara harapan konsumen dan kinerja aktual dari produk atau layanan yang diberikan (Santouridis, 2009). Dengan demikian, konsumen merasa puas atau tidak sangat tergantung pada pelayanan yang diterimanya apakah sesuai dengan harapannya. Kepuasan pelanggan adalah hasil dari persepsi pelanggan tentang nilai yang diterima dalam suatu transaksi atau hubungan, dimana nilai sama dengan kualitas yang dipersepsikan. Lebih lanjut, Fornell, (1992) dalam Santouridis (2009) menyatakan kepuasan dapat meningkatkan loyalitas pelanggan, menurunkan sensitivitas harga, dan mengurangi biaya pemasaran dan penciptaan pelanggan baru, mengurangi biaya operasi karena peningkatan jumlah pelanggan, meningkatkan efektivitas iklan dan meningkatkan reputasi bisnis.

\subsection{Desain Kerangka Pikir}

Berdasarkan kajian teori yang telah dibahas dimembuat alur penelitian yang tertuang dalam Gambar 3, sebagai berikut: 


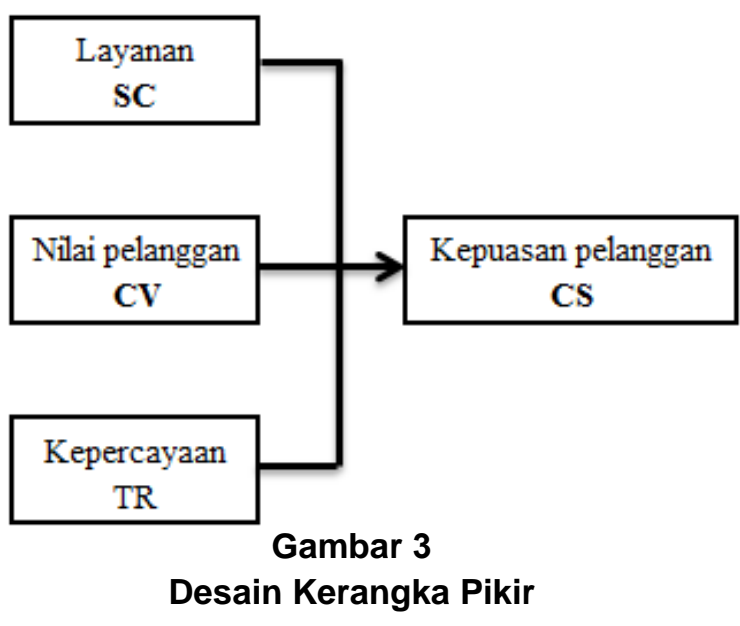

Keterangan:

1. Pengaruh Layanan (SC) terhadap Kepuasan Pelanggan (CS).

2. Pengaruh Nilai Pelanggan (CV) terhadap Kepuasan Pelanggan (CS).

3. Pengaruh Kepercayaan (TR) terhadap Kepuasan Pelanggan (CS).

\subsection{Structural Equation Modeling (SEM)} Sholiha dan Salamah (2015) menjelaskan bahwa Structural Equation Modeling (SEM) merupakan metode analisis multivariat yang dapat digunakan untuk menggambarkan keterkaitan hubungan linier secara simultan antara variabel pengamatan (indikator) dan variabel yang tidak dapat diukur secara langsung (variabel laten).

Variabel laten merupakan variabel tak teramati (unobser-ved) atau tak dapat diukur (unmeasured) secara langsung, melainkan harus diukur melalui beberapa indikator. Terdapat dua tipe variabel laten dalam SEM yaitu endogen ( $\eta$ ) dan ek-sogen (६) (Sholiha, Eva Ummi Nikmatus., \& Salamah, 2015).

\subsection{Partial Least Square (PLS)}

Partial Least Square (PLS) menjadi metode yang kuat dari suatu analisis karena kurangnya ketergantungan pada skala pengukuran (misal pengukuran yang membutuhkan skala interval atau rasio), ukuran sampel, dan distribusi dari residual. Indikator pada PLS bisa dibentuk dengan tipe refleksif atau formatif (Sholiha, Eva Ummi Nikmatus., \& Salamah, 2015).

Model struktural menggambarkan hubungan antara variabel laten independen (eksogen) dengan variabel laten dependen (endogen) dengan persamaan sebagai berikut:

\section{$\eta=B \eta+\Gamma \xi+\zeta$}

Dimana $\eta$ (eta) adalah vektor random variabel laten endogen dengan ukuran $\mathrm{mx} 1, \xi$ (xi) adalah vektor random variabel laten eksogen dengan ukuran $\mathrm{n} \times 1$, B adalah matriks koefisien variabel laten endogen berukuran $\mathrm{mxm}$ dan $\Gamma$ matriks koefisien variabel laten eksogen, yang menunjukkan hubungan dari $\xi$ terhadap $\eta$ berukuran $m \times n$. Sedangkan $\zeta$ (zeta) adalah vektor random error berukuran $\mathrm{m} \times 1$. Asumsi persamaan model struktural variabel laten antara lain: $E(\eta)=0, E(\xi)=0, E(\zeta)=0$, dan $\boldsymbol{\zeta}$ tidak berkorelasi dengan $\boldsymbol{\xi}$ dan $(\mathbf{I}-\mathbf{B})$ adalah matriks nonsingular.

Model pengukuran (measurement model) adalah bagian dari suatu model persamaan struktural yang menggambarkan hubungan variabel laten dengan indikatorindikatornya yang secara umum dimodelkan sebagai berikut :

$$
\begin{aligned}
\mathbf{y}_{(p \times 1)} & =\Lambda_{y(p \times m)} \boldsymbol{\eta}_{(m \times 1)}+\boldsymbol{\varepsilon}_{(p \times 1)} \\
\mathbf{x}_{(q \times 1)} & =\Lambda_{x(q \times n)} \boldsymbol{\xi}_{(n \times 1)}+\boldsymbol{\delta}_{(q \times 1)}
\end{aligned}
$$

$\Lambda y$ : matrik loading antara variabel endogen dan indikatornya.

$\Lambda x$ : matrik loading antara variabel eksogen dan indikatornya.

$\varepsilon$ : $\quad$ vektor pengukuran error dari

$\delta$. indikator variabel endogen.

$\delta$ : $\quad$ vektor pengukuran error dari indikator variabel eksogen.

$p$ : banyaknya variabel laten endogen

$q$ : banyaknya variabel laten eksogen.

$m$ : banyaknya indikator variabel endogen.

$n$ : banyaknya indikator variabel eksogen.

Model pengukuran mempunyai asumsi bahwa $E(\boldsymbol{\varepsilon})=E(\boldsymbol{\delta})=0, \boldsymbol{\varepsilon}$ tidak berkorelasi dengan $\eta$, $\boldsymbol{\xi}$, dan $\boldsymbol{\delta}$, serta $\boldsymbol{\delta}$ tidak berkorelasi dengan $\eta$, $\boldsymbol{\xi}$, dan.

Selain itu, juga terdapat weight relation (hubungan bobot) yaitu bobot yang menghubungkan inner model dan outer model untuk membentuk estimasi variabel laten eksogen dan endogen. Nilai kasus untuk setiap variabel laten diestimasi dalam PLS sebagai berikut :

$$
\begin{aligned}
\hat{\xi} & =\sum_{k} \mathbf{w}_{k b} \mathbf{x}_{k b} \\
\widehat{\mathbf{\eta}}_{i} & =\sum_{k} \mathbf{w}_{k i} \mathbf{y}_{k i}
\end{aligned}
$$


Dimana $\mathbf{w} k b$ dan $\mathbf{w} k i$ adalah weight ke-k yang digunakan untuk mengestimasi variabel laten $\xi b$ dan varaibel laten $\eta i$. Metode estimasi parameter yang digunakan pada PLS adalah Ordinary Least Square (OLS) (Sholiha, Eva Ummi Nikmatus., \& Salamah, 2015).

\section{Metode Penelitian}

\subsection{Jenis/Desain Penelitian}

Penelitian ini menggunakan pendekatan kuantitatif dengan desain eksplanatif atau kausal yang bertujuan untuk menjelaskan bagaimana satu variabel mempengaruhi atau bertanggung jawab atas perubahan-perubahan dalam variabel lainnya (Cooper, D.R., \& Schindler, P.S, 2011).

Penelitian secara cross-sectional yaitu suatu jenis penelitian yang melakukan pengumpulan informasi/kuesioner hanya satu kali dalam satu waktu tertentu kepada sampel (Malhotra, 2007). Data crosssectional dikumpulkan sekaligus pada satu saat tertentu dan hanya sekali saja dengan cara menyebarkan kuesioner kepada para responden.

Metode survei adalah pengumpulan informasi berdasarkan pada kuesioner responden (Malhotra, 2007). Dengan demikian penelitian ini tergolong dalam metode survei di mana peneliti menggunakan instrumen kuesioner untuk memperoleh data ke subjek peneliti dalam jangka waktu yang relatif singkat.

\subsection{Definisi Operasional dan Pengukuran Variabel \\ Definisi operasional menjelaskan} suatu konsep yang membuat suatu variabel terukur melalui dimensinya, aspek tertentu, atau atribut yang menempel pada sebuah konsep tersebut (Sekaran, 2007:176). Definisi operasional dalam penelitian ini berupa seperangkat petunjuk yang lengkap tentang apa yang harus diamati dan bagaimana mengukur variabel-variabel yang digunakan dalam penelitian.

\subsection{Teknik Pengumpulan Data}

Dalam penelitian menggunakan tipe kuesioner tertutup, jadi responden tinggal memilih jawaban yang sesuai dengan keinginannya, pertanyaan tertutup akan membantu responden untuk menjawab dengan cepat, dan juga memudahkan peneliti dalam melakukan analisis data terhadap seluruh angket yang telah terkumpul. Teknik penyebaran kuesioner dilakukan dengan membagikan angket secara langsung kepada pelanggan Fixpay melalui google form.

\subsection{Populasi dan Sampel}

Populasi penelitian ini adalah pelanggan Fixpay. Metode pengambilan sampel menggunakan teknik non probability sampling, karena setiap unsur yang terdapat dalam populasi tidak memiliki kesempatan atau peluang yang sama untuk dipilih sebagai sampel (Siregar, 2013:34). Jumlah sampel dalam penelitian ini tidak diketahui, maka teknik yang digunakan untuk menentukan ukuran sampel berdasarkan pendekatan Isac Michel, yang menyebutkan minimum jumlah sampel yang harus di ambil sebesar 57 orang (Siregar, 2013:34). Berdasarkan teori tersebut, maka jumlah sampel yang digunakan oleh peneliti yaitu sebanyak 100 responden.

\subsection{Metode Analisis Data}

Metode analisis data dalam penelitian ini menggunakan model path analysis (analisis jalur) digunakan untuk menganalisis pola hubungan di antara variabel. Model ini bertujuan untuk mengetahui pengaruh langsung maupun tidak langsung seperangkat variabel bebas (eksogen) terhadap variabel terikat (endogen) (Ridwan dan Kuncoro, 2008 dalam Sarjono dan Julianita, 2011:117). Ghozali (2013:249) menjelaskan analisis jalur merupakan peluasan dari analisis regresi linear berganda, atau analisis jalur adalah penggunaan analisis regresi untuk menaksir hubungan kausalitas antara variabel (model casual) yang telah ditetapkan sebelumnya berdasarkan teori. Pengukuran keempat variabel mengikuti dimensi dan indikator berdasarkan Tabel 1. 
Tabel 1. Pengukuran Variabel

\begin{tabular}{|c|c|c|c|c|}
\hline No & Variabel & Dimensi & Indikator & Skala \\
\hline \multirow[t]{9}{*}{1} & \multirow{9}{*}{$\begin{array}{l}\text { Kualitas } \\
\text { Pelayana } \\
\mathrm{n} / / \\
\text { Service } \\
\text { Quality } \\
\\
\text { (Parasuramanet. } \\
\text { al., 2005) } \\
\text { Dalam (Tjiptono, } \\
\text { 2014:303) }\end{array}$} & \multirow[t]{3}{*}{ Efficiency } & $\begin{array}{l}\text { Tingkat kemudahan menemukan informasi } \\
\text { pemberitahuan pada aplikasi Fixpay }\end{array}$ & \multirow[t]{9}{*}{ Ordinal } \\
\hline & & & $\begin{array}{l}\text { Kemampuan pelanggan mengakses ke } \\
\text { aplikasi }\end{array}$ & \\
\hline & & & $\begin{array}{l}\text { Tingkat kecepatan proses mengakses dan } \\
\text { meninggalkan aplikasi }\end{array}$ & \\
\hline & & \multirow[t]{2}{*}{ Fulfillment } & Tingkat kecepatan konfirmasi layanan & \\
\hline & & & Ketersediaan stok produk & \\
\hline & & \multirow{2}{*}{$\begin{array}{l}\text { System } \\
\text { Availability }\end{array}$} & Aplikasi berfungsi dengan baik & \\
\hline & & & $\begin{array}{l}\text { Tingkat kemudahan mengoperasikan } \\
\text { aplikasi }\end{array}$ & \\
\hline & & \multirow[t]{2}{*}{ Privacy } & $\begin{array}{l}\text { Tingkat keamanan saat proses } \\
\text { penggunaan layanan berlangsung }\end{array}$ & \\
\hline & & & Tingkat keamanan finansial & \\
\hline \multirow[t]{4}{*}{2} & \multirow{4}{*}{$\begin{array}{l}\text { Nilai Pelanggan / } \\
\text { Customer Value } \\
\text { (Sweeney dan } \\
\text { Soutar, 2001) } \\
\text { Dalam (Chi dan } \\
\text { Kilduff, 2011) }\end{array}$} & Emotional Value & $\begin{array}{l}\text { Utilitas yang berasal dari perasaan atau } \\
\text { afektif/emosi positif yang ditimbulkan dari } \\
\text { mengkonsumsi produk }\end{array}$ & \multirow[t]{4}{*}{ Ordinal } \\
\hline & & Social Value & $\begin{array}{l}\text { Utilitas yang didapatkan dari kemampuan } \\
\text { produk untuk meningkatkan konsepdiri } \\
\text { sosial konsumen }\end{array}$ & \\
\hline & & $\begin{array}{l}\text { Performanc } \\
\text { e Value }\end{array}$ & $\begin{array}{l}\text { Utilitas yang diperoleh dari persepsi } \\
\text { terhadap kualitas dan kinerja yang } \\
\text { diharapkan atasproduk }\end{array}$ & \\
\hline & & Value for Money & $\begin{array}{l}\text { Utilitas yang didapatkan dari produk } \\
\text { berkenaan reduksi biaya jangka pendek } \\
\text { dan biaya jangka panjang }\end{array}$ & \\
\hline \multirow[t]{10}{*}{3} & \multirow{10}{*}{$\begin{array}{l}\text { Kepercayaan / } \\
\text { Trust } \\
\text { (Mayer, 1995) } \\
\text { Dalam (Rofiq dan } \\
\text { Mula, 2010) }\end{array}$} & \multirow{4}{*}{$\begin{array}{l}\text { Ability } \\
\text { (Kemampuan) }\end{array}$} & Pengalaman & \multirow[t]{3}{*}{ Ordinal } \\
\hline & & & Kompetensi & \\
\hline & & & $\begin{array}{l}\text { Kemampuan dalam ilmu } \\
\text { Pengetahuan }\end{array}$ & \\
\hline & & & Pengesahan institusional & \\
\hline & & \multirow{3}{*}{$\begin{array}{l}\text { Benevolence } \\
\text { (Kebaikan Hati) }\end{array}$} & Empati & \\
\hline & & & Keyakinan & \\
\hline & & & Daya diterima & \\
\hline & & \multirow{3}{*}{$\begin{array}{l}\text { Integrity } \\
\text { (Integritas) }\end{array}$} & Pemenuhan & \\
\hline & & & Keterusterangan & \\
\hline & & & Kehandalan & \\
\hline \multirow[t]{9}{*}{4} & \multirow{9}{*}{$\begin{array}{l}\text { Kepuasan } \\
\text { Konsume } \\
\mathrm{n} / \\
\text { Customer } \\
\text { Satisfactio } \\
n \\
\text { (Lupiyoadi, 2014) }\end{array}$} & Kualitas Produk & $\begin{array}{l}\text { Memberikan pelayanan sesuai dengan } \\
\text { yang dijanjikan }\end{array}$ & \multirow[t]{9}{*}{ Ordinal } \\
\hline & & \multirow[t]{2}{*}{$\begin{array}{l}\text { Kualitas } \\
\text { Pelayanan }\end{array}$} & $\begin{array}{l}\text { Pelayanan sesuai dengan harapan } \\
\text { konsumen }\end{array}$ & \\
\hline & & & Pelayanan yang cepat tanggap & \\
\hline & & Emosional & $\begin{array}{l}\text { Ada perasaan bangga setelah } \\
\text { menggunakan produk }\end{array}$ & \\
\hline & & \multirow[t]{3}{*}{ Harga } & $\begin{array}{l}\text { Harga yang dibayarkan sesuai dengan } \\
\text { kualitas }\end{array}$ & \\
\hline & & & $\begin{array}{l}\text { Harga yang dibayarkan sesuai dengan } \\
\text { kuantitas produk }\end{array}$ & \\
\hline & & & $\begin{array}{l}\text { Harga sesuai dengan harapan } \\
\text { Konsumen }\end{array}$ & \\
\hline & & \multirow{2}{*}{$\begin{array}{l}\text { Biaya dan } \\
\text { Kemudahan }\end{array}$} & Kemudahan mendapatkan produk & \\
\hline & & & Kepuasan dengan produk & \\
\hline
\end{tabular}


3. Hasil dan Pebahasan 3.1. Profil Responden

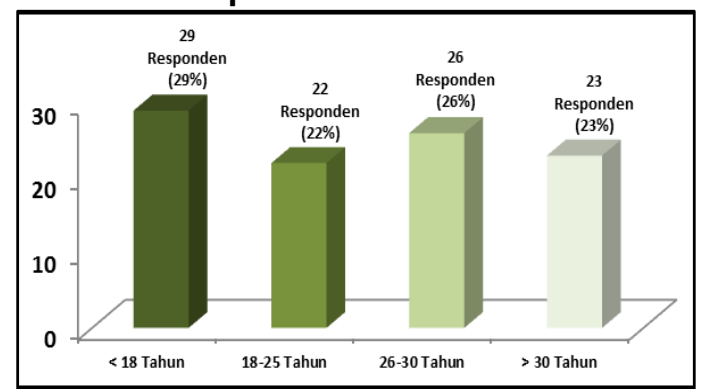

Gambar 4. Profil Responden Berdasarkan Usia

Berdasarkan Gambar 4 di atas, responden yang menyatakan berusia kurang dari 18 tahun sebanyak 29 responden $(29,0 \%)$. Sedangkan responden yang berusia $18-25$ tahun sebanyak 22 responden $(22,0 \%)$. Responden yang menyatakan berusia 26-30 tahun sebanyak 26 responden $(26,0 \%)$ dan sisanya 23 responden $(23,0 \%)$ menyatakan berusia lebih dari 30 tahun

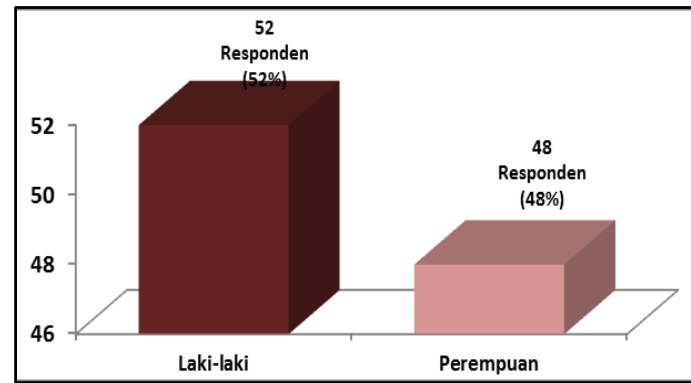

Gambar 5. Profil Responden Berdasarkan Jenis Kelamin

Berdasarkan Gambar 5, mayoritas responden berjenis kelamin pria sebanyak 52 responden $(52,0 \%)$ dan sisanya 48 responden $(48,0 \%)$ menyatakan berjenis kelamin wanita.

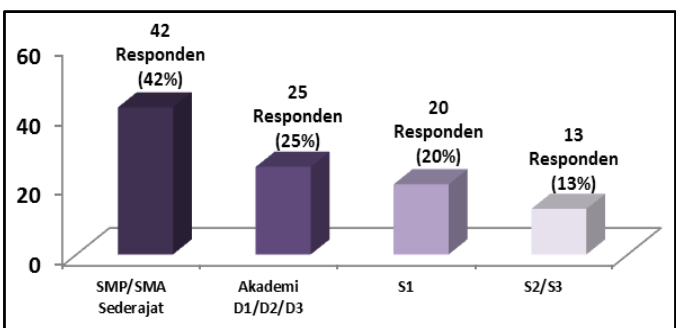

Gambar 6. Profil Responden Berdasarkan Pendidikan Terakhir

Berdasarkan Gambar 6, responden yang pendidikan terakhir SMP/SMA sederajat sebanyak 42 responden (42,0\%). Responden yang pendidikan terakhir Akademi D1/D2/D3 sebanyak 25 responden $(25,0 \%)$. Sedangkan responden yang pendidikan terakhir Sarjana sebanyak 20 responden $(20,0 \%)$ dan sisanya 13 responden (13,0\%) menyatakan pendidikan terakhir lebih dari Sarjana.

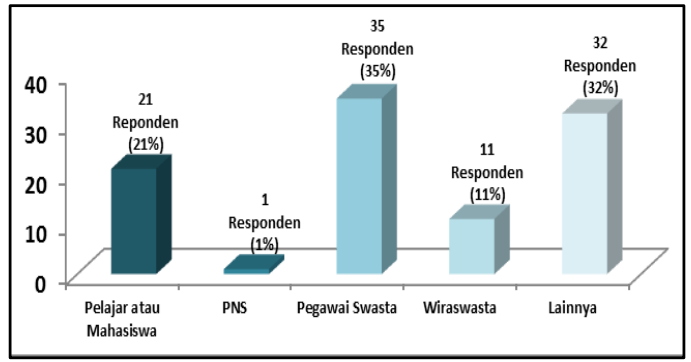

\section{Gambar 7. Profil Responden Berdasarkan Pekerjaan}

Berdasarkan Gambar 7 di atas, mayoritas pekerjaan responden sebagai pegawai swasta sebanyak 35 responden $(35,0 \%)$. Sedangkan pekerjaan responden yang sebagai pelajar/mahasiswa sebanyak 21 responden $(21,0 \%)$. Responden yang pekerjaannya sebagai pegawai negeri sebanyak 1 responden $(1,0 \%)$. Selanjutnya responden yang pekerjaannya wiraswasta sebanyak 11 responden $(11,0 \%)$ dan sisanya 32 responden $(32,0 \%)$ menyatakan pekerjaan lainnya.

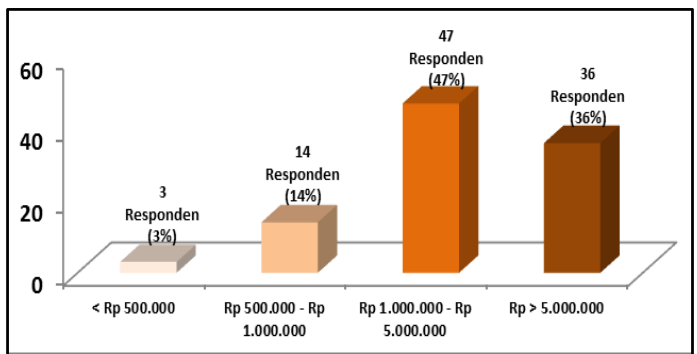

Gambar 8. Profil Responden Berdasarkan Penghasilan Perbulan

Berdasarkan Gambar 8, responden yang menyatakan penghasilan perbulan kurang dari $\mathrm{Rp} 500.000$ sebanyak 3 responden $(3,0 \%)$. Sedangkan responden yang menyatakan penghasilan perbulannya Rp 500.000 - Rp 1.000 .000 sebanyak 14 responden $(14,0 \%)$. Selanjutnya responden yang menyatakan penghasilan perbulannya Rp 1.000.000 - Rp 5.000.000 sebanyak 47 responden $(47,0 \%)$ dan sisanya 36 responden $(36,0 \%)$ menyatakan penghasilan perbulannya lebih dari $\mathrm{Rp} 5.000 .000$. 


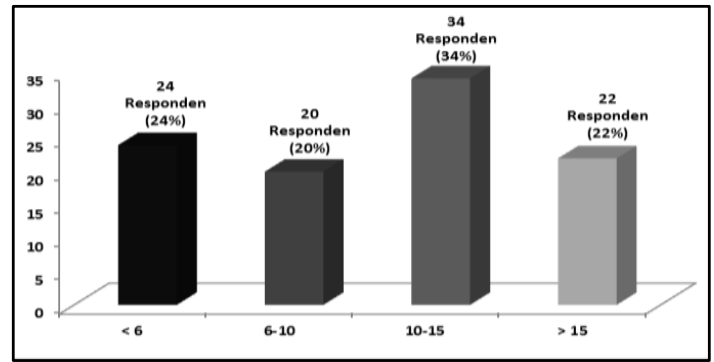

Gambar 9. Profil Responden Berdasarkan Jumlah Transaksi

Berdasarkan Gambar 9 di atas, responden yang melakukan transaksi sebanyak kurang dari 24 responden $(24,0 \%)$. Sedangkan responden yang melakukan transaksi 6 hingga 10 kali sebanyak 20 responden (20,0\%). Responden yang melakukan transaksi 10 hingga 15 kali sebanyak 34 responden $(34,0 \%)$ dan sisanya 22 responden $(22,0 \%)$ melakukan transaksi lebih dari 15 kali.

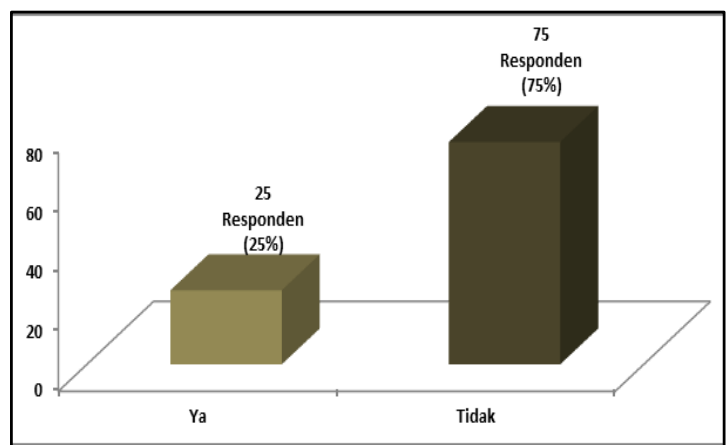

Gambar 10. Profil Responden Berdasarkan Apakah anda pernah menggunakan aplikasi lain selain Fixpay

Berdasarkan Gambar 10, mayoritas responden yang menjawab tidak menggunakan aplikasi lain selain Fixpay sebanyak 75 responden $(75,0 \%)$ dan sisanya 25 responden $(25,0 \%)$ menjawab ya untuk menggunakan aplikasi lain selain Fixpay.

\subsection{Uji Validitas Dan Reliabilitas}

Tabel 2. Hasil Uji Validitas dan Reliabilitas

\begin{tabular}{|c|c|c|c|c|}
\hline Variabel & Indikator & $\begin{array}{c}\text { Factor } \\
\text { Loading }\end{array}$ & AVE & $\begin{array}{l}\text { Composite } \\
\text { Reliability }\end{array}$ \\
\hline \multirow{9}{*}{$\begin{array}{l}\text { Service } \\
\text { Quality }\end{array}$} & SQ1 & 0,850 & \multirow{9}{*}{0,710} & \multirow{9}{*}{0,957} \\
\hline & SQ2 & 0,859 & & \\
\hline & SQ3 & 0,826 & & \\
\hline & SQ4 & 0,857 & & \\
\hline & SQ5 & 0,841 & & \\
\hline & SQ6 & 0,871 & & \\
\hline & SQ7 & 0,819 & & \\
\hline & SQ8 & 0,826 & & \\
\hline & SQ9 & 0,830 & & \\
\hline \multirow{4}{*}{$\begin{array}{c}\text { Customer } \\
\text { Value }\end{array}$} & CV1 & 0,803 & \multirow{4}{*}{0,694} & \multirow{4}{*}{0,948} \\
\hline & CV2 & 0,836 & & \\
\hline & CV3 & 0,790 & & \\
\hline & CV4 & 0,845 & & \\
\hline
\end{tabular}

\begin{tabular}{|c|c|c|c|c|}
\hline Variabel & Indikator & $\begin{array}{c}\text { Factor } \\
\text { Loading }\end{array}$ & AVE & $\begin{array}{l}\text { Composite } \\
\text { Reliability }\end{array}$ \\
\hline & CV5 & 0,842 & & \\
\hline & CV6 & 0,868 & & \\
\hline & CV8 & 0,843 & & \\
\hline & CV9 & 0,837 & & \\
\hline \multirow{10}{*}{ Trust } & TR1 & 0,860 & \multirow{10}{*}{0,752} & \multirow{10}{*}{0,968} \\
\hline & TR2 & 0,870 & & \\
\hline & TR3 & 0,895 & & \\
\hline & TR4 & 0,869 & & \\
\hline & TR5 & 0,848 & & \\
\hline & TR6 & 0,883 & & \\
\hline & TR7 & 0,882 & & \\
\hline & TR8 & 0,839 & & \\
\hline & TR9 & 0,861 & & \\
\hline & TR10 & 0,864 & & \\
\hline \multirow{9}{*}{$\begin{array}{l}\text { Customer } \\
\text { Satisfaction }\end{array}$} & CS1 & 0,814 & \multirow{9}{*}{0,685} & \multirow{9}{*}{0,951} \\
\hline & CS2 & 0,830 & & \\
\hline & CS3 & 0,806 & & \\
\hline & CS4 & 0,813 & & \\
\hline & CS5 & 0,810 & & \\
\hline & CS6 & 0,827 & & \\
\hline & CS7 & 0,876 & & \\
\hline & CS8 & 0,821 & & \\
\hline & CS9 & 0,850 & & \\
\hline
\end{tabular}

Berdasarkan Tabel 2 terlihat bahwa semua item kuesioner telah memenuhi standar uji validitas konvergen yaitu AVE di atas 0,5 dan factor loading di atas 0,5 yang berarti bahwa seluruh item dinyatakan valid, serta telah memenuhi standar uji composite reliability yaitu lebih besar dari 0,7 yang berarti bahwa seluruh item dinyatakan reliable.

\subsection{Uji Validitas Diskriminan}

Tabel 3. Fornell Larcker Criterion

\begin{tabular}{|l|l|r|l|l|}
\hline & CS & CV & SQ & TR \\
\hline CS & 0.828 & & & \\
\hline CV & 0,820 & $\begin{array}{r}0.83 \\
3\end{array}$ & & \\
\hline SQ & 0.832 & $\begin{array}{r}0.82 \\
4\end{array}$ & 0.842 & \\
\hline TR & 0,799 & $\begin{array}{r}0,79 \\
4\end{array}$ & 0,726 & 0.867 \\
\hline
\end{tabular}

Pada Tabel 3 terlihat semua konstruk terbukti memiliki validitas diskriminan yang tinggi. Hal tersebut terlihat dari nilai AVE tiap tiap konstruk lebih tinggi dibanding dengan korelasi konstruk itu dengan konstruk lainnya.

Tabel 4. Cross Loading

\begin{tabular}{|l|c|c|c|c|}
\hline & CS & CV & SQ & TR \\
\hline CS1 & 0.814 & 0.688 & 0.712 & 0.651 \\
\hline CS2 & 0.830 & 0.696 & 0.753 & 0.669 \\
\hline CS3 & 0.806 & 0.641 & 0.631 & 0.652 \\
\hline CS4 & 0.813 & 0.637 & 0.633 & 0.643 \\
\hline CS5 & 0.810 & 0.654 & 0.698 & 0.619 \\
\hline CS6 & 0.827 & 0.698 & 0.662 & 0.684 \\
\hline CS7 & 0.876 & 0.697 & 0.700 & 0.624 \\
\hline CS8 & 0.821 & 0.720 & 0.727 & 0.688 \\
\hline CS9 & 0.850 & 0.671 & 0.667 & 0.714 \\
\hline CV1 & 0.667 & 0.803 & 0.687 & 0.645 \\
\hline CV2 & 0.610 & 0.836 & 0.610 & 0.703 \\
\hline
\end{tabular}




\begin{tabular}{|c|c|c|c|c|}
\hline & CS & CV & SQ & TR \\
\hline CV3 & 0.608 & 0.790 & 0.651 & 0.630 \\
\hline CV4 & 0.668 & 0.845 & 0.646 & 0.651 \\
\hline CV5 & 0.721 & 0.842 & 0.686 & 0.672 \\
\hline CV6 & 0.760 & 0.868 & 0.729 & 0.680 \\
\hline CV7 & 0.713 & 0.843 & 0.759 & 0.659 \\
\hline CV8 & 0.699 & 0.837 & 0.712 & 0.659 \\
\hline SQ1 & 0.714 & 0.672 & 0.850 & 0.586 \\
\hline SQ2 & 0.670 & 0.716 & 0.859 & 0.559 \\
\hline SQ3 & 0.675 & 0.632 & 0.826 & 0.599 \\
\hline SQ4 & 0.708 & 0.736 & 0.857 & 0.614 \\
\hline SQ5 & 0.718 & 0.672 & 0.841 & 0.546 \\
\hline SQ6 & 0.711 & 0.771 & 0.871 & 0.640 \\
\hline SQ7 & 0.673 & 0.670 & 0.819 & 0.634 \\
\hline SQ8 & 0.682 & 0.686 & 0.826 & 0.673 \\
\hline SQ9 & 0.746 & 0.691 & 0.830 & 0.653 \\
\hline TR1 & 0.705 & 0.686 & 0.647 & 0.860 \\
\hline TR2 & 0.698 & 0.659 & 0.657 & 0.870 \\
\hline TR3 & 0.700 & 0.683 & 0.611 & 0.895 \\
\hline TR4 & 0.697 & 0.691 & 0.620 & 0.869 \\
\hline TR5 & 0.727 & 0.708 & 0.645 & 0.848 \\
\hline TR6 & 0.654 & 0.705 & 0.614 & 0.883 \\
\hline TR7 & 0.661 & 0.705 & 0.663 & 0.882 \\
\hline TR8 & 0.669 & 0.701 & 0.658 & 0.839 \\
\hline TR9 & 0.698 & 0.678 & 0.554 & 0.861 \\
\hline TR10 & 0.708 & 0.668 & 0.628 & 0.864 \\
\hline
\end{tabular}

Pada Tabel 4 setiap blok indikator memiliki loading lebih tinggi untuk setiap variabel laten yang diukur dibandingkan dengan indikator untuk variabel laten lainnya sehingga semua konstruk terbukti memiliki validitas diskriminan yang tinggi.

\subsection{Uji Asumsi Klasik \\ Uji Multikolinieritas}

Berdasarkan hasil pengujian multikolinearitas pada Tabel 5, dapat diketahui bahwa variabel service quality (SQ), customer value (CV) dan trust (TR) memperoleh nilai $\mathrm{VIF}<10$. Hasil tersebut mengindikasikan bahwa tidak memiliki gejala masalah multikolinearitas diantara variabel independen.

Tabel 5. Hasil Uji Multikolinearitas

\begin{tabular}{|l|c|}
\hline Variabel & \multicolumn{1}{|c|}{ VIF } \\
\hline Service Quality (SQ) & 3,262 \\
\hline Customer Value (CV) & 4,172 \\
\hline Trust (TR) & 2,829 \\
\hline
\end{tabular}

\section{Regresi Berganda}

Pengujian regresi berganda dibantu dengan menggunakan program Smart PLS versi 3. Proses running dilakukan dengan 2 tahap yaitu PLS Algorithm dan Bootstraping. PLS Algorithm befungsi untuk menampilkan uji instrumen penelitian yang ditampilkan pada output Factor Loading, AVE dan Composite Realibility, Fornell Larcker Criterion, dan Cross Loading. Sedangkan PLS Bootstraping berfungsi untuk menampilkan uji regresi berganda dengan menampilkan output $\mathrm{t}$ dan nilai koefisien masing-masing.

Hasil output nilai koefisen pada model regresi setelah proses running data dapat dilihat pada Gambar 11 berikut:

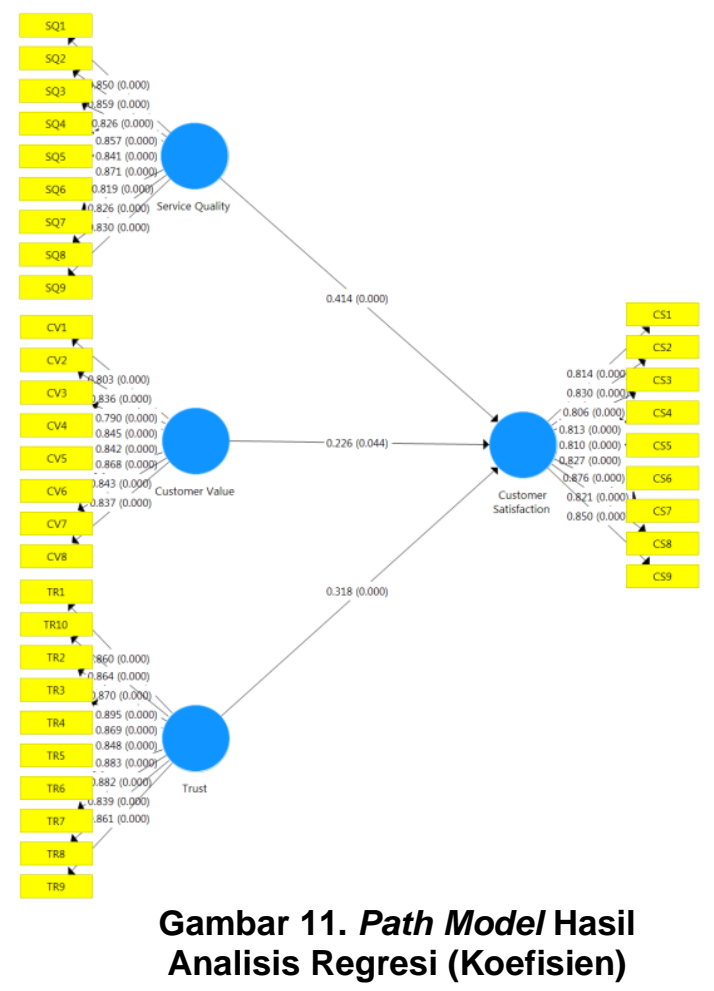

Setelah diperoleh output nilai koefisen pada model analisis regresi di atas, kemudian dipeoleh hasil PLS Bootstraping untuk menampilkan uji analisis regresi dengan menampilkan output $\mathrm{t}$-test seperti yang terlihat pada Gambar 12 berikut:

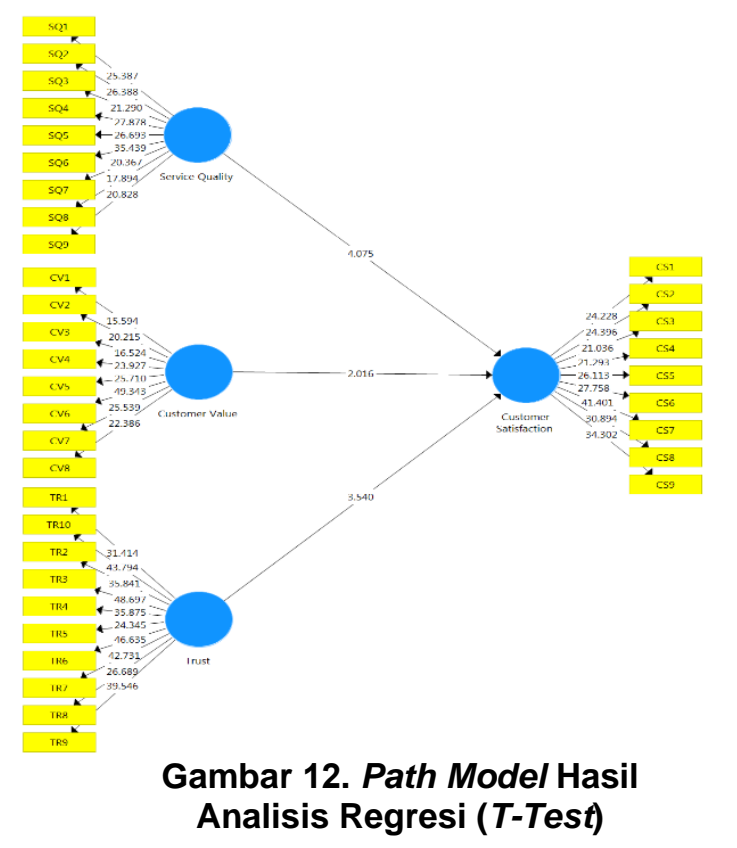


Dengan tingkat signifikansi (a) yang digunakan sebesar $5 \%(0,05)$. Hasil uji analisis regresi berganada untuk nilai signifikansi (P-Value) dapat dilihat pada output Gambar 13 dan Tabel 6 berikut ini.

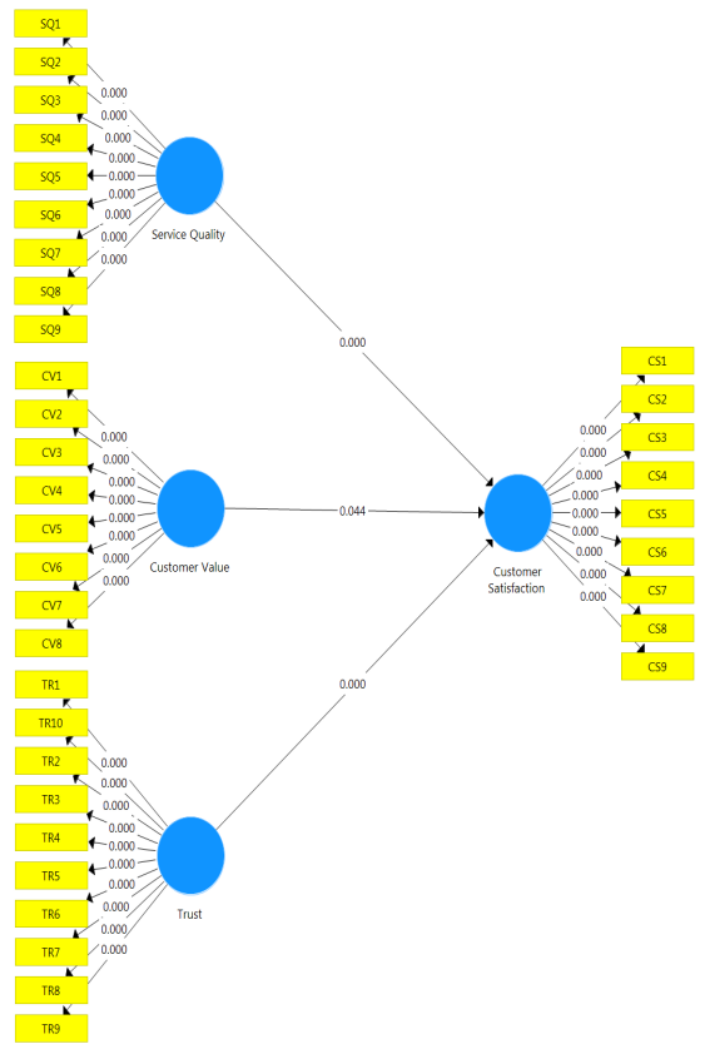

Gambar 13. Path Model Hasil Analisis Regresi (P-Value)

Hasil Uji Regresi Berganda Tabel 6. Hasil Uji Regresi Berganda

\begin{tabular}{|c|c|c|c|c|c|}
\hline & $\begin{array}{l}\text { Orig } \\
\text { inal } \\
\text { Sam } \\
\text { ple } \\
\text { (0) }\end{array}$ & $\begin{array}{l}\text { Sampl } \\
\text { e } \\
\text { Mean } \\
\text { (M) }\end{array}$ & $\begin{array}{l}\text { Stan } \\
\text { dard } \\
\text { Devia } \\
\text { tion } \\
\text { (STD } \\
\text { EV) }\end{array}$ & $\begin{array}{l}\text { T } \\
\text { Statis } \\
\text { tics } \\
(\mid \mathrm{O} / \mathrm{S} \\
\text { TDEV } \\
\text { |) }\end{array}$ & $\begin{array}{l}\text { P } \\
\text { Valu } \\
\text { es }\end{array}$ \\
\hline$C V \rightarrow C S$ & $\begin{array}{r}0.22 \\
6 \\
\end{array}$ & 0.233 & 0.108 & 2,095 & 0.037 \\
\hline $\begin{array}{l}\text { SQ -> } \\
\mathrm{CS}\end{array}$ & $\begin{array}{r}0,41 \\
4 \\
\end{array}$ & 0,410 & 0.107 & 3,878 & 0.000 \\
\hline TR $->$ CS & $\begin{array}{r}0.31 \\
8 \\
\end{array}$ & 0.317 & 0.088 & 3,630 & 0.000 \\
\hline
\end{tabular}

Persamaan Regresi sebagai berikut:

$$
Y=0,784+0,226 X 1+0,414 X 2+0,318 X 3+e
$$

Berdasarkan Tabel di atas, hasil hipotesis pada variabel customer value (CV) terhadap customer satisfaction (CS) menghasilkan nilai t-hitung sebesar 2,095 > ttabel 1,966 dengan nilai signifikan sebesar $0,000<0,05$. Dengan demikian variabel customer value (CV) memiliki pengaruh yang signifikan terhadap customer satisfaction (CS).

Kemudian variabel service quality (SQ) terhadap customer satisfaction (CS) menghasilkan nilai t-hitung sebesar 3,878 > ttabel 1,966 dengan nilai signifikan sebesar $0,000<0,05$. Dengan demikian variabel service quality (SQ) memiliki pengaruh yang signifikan terhadap customer satisfaction (CS).

Sementara itu, variabel trust (TR) terhadap customer satisfaction (CS) menghasilkan nilai t-hitung sebesar 3,630 > ttabel 1,966 dengan nilai signifikan sebesar $0,000<0,05$ Dengan demikian variabel trust (TR) memiliki pengaruh yang signifikan terhadap customer satisfaction (CS).

Hasil Uji Koefisien Determinasi

Tabel 7. Hasil Uji Koefisien Determinasi

\begin{tabular}{|l|r|r|}
\hline & R Square & $\begin{array}{l}\text { R Square } \\
\text { Adjusted }\end{array}$ \\
\hline CS & 0.784 & 0.778 \\
\hline
\end{tabular}

Setelah mendapatkan hasil regresi didapatkan nilai $R^{2}$ (Koefisien determinasi) pada penelitian ini adalah 0,778. Artinya bahwa kemampuan variabel bebas dalam menjelaskan varians dari variabel terikatnya adalah sebesar 77,8\%. Sehingga 22,2\% varians variabel terikat (customer satisfaction) dijelaskan oleh faktor lain.

\section{Kesimpulan}

Hipotesis pertama membuktikan bahwa consumer value terbukti berpengaruh signifikan terhadap customer satisfaction. Hal ini menunjukkan semakin tinggi nilai pelanggan maka akan semakin tinggi tingkat kepuasan pelanggan. Hasil ini mendukung penelitian terdahulu yang dilakukan oleh Chen, Basit, dan Hassan (2017).

Hipotesis kedua menunjukkan bahwa service quality memiliki pengaruh signifikan terhadap consumer satisfaction. Hasil ini mendukung penelitian Sobihah, et al., (2015) yang menjelaskan bahwa kualitas pelayanan berpengaruh terhadap kepuasan pelanggan. Hal ini menunjukkan bahwa semakin baik kualitas pelayanan yang diberikan oleh pelanggan maka akan berdampak pada meningkatnya kepuasan pelanggan pada Fixpay.

Hipotesis ketiga membuktikan bahwa trust terbukti memiliki pengaruh yang signifikan terhadap customer satisfaction. 
Hasil penelitian ini mendukung Anh (2015) yang menjelaskan bahwa kepercayaan merupakan faktor utama yang mempengaruhi kepuasan pelanggan. Hasil hipotesis menunjukkan bahwa semakin tinggi kepercayaan maka akan semakin tinggi tingkat kepuasan pelanggan pada Fixpay.

Secara bersama-sama terbukti bahwa Customer value, Service quality dan Trust secara bersama-sama berpengaruh terhadap customer satisfaction dengan besaran pengaru sebesar $77,80 \%$. Hasil menunjukkan bahwa ketiga faktor tersebut memiliki pengaruh kuat dalam meningkatkan kepuasan pelanggan Fixpay.

Berdasarkan hasil penelitian yang telah dilakukan, maka diperoleh beberapa kesimpulan sebagai berikut:

1. Nilai Pelanggan terbukti memiliki pengaruh yang signifikan terhadap kepuasan pelanggan.

2. Layanan terbukti memiliki pengaruh yang signifikan terhadap kepuasan pelanggan.

3. Kepercayaan terbukti memiliki pengaruh yang signifikan terhadap kepuasan pelanggan.

4. Nilai Pelanggan, layanan, dan kepercayaan secara bersama-sama berpengaruh terhadap kepuasan pelanggan dengan besaran pengaruh sebesar $77,80 \%$.

Disarankan kepada pihak perusahaan untuk terus meningkatkan kepuasan pelanggan, seperti dengan membuat mudah aplikasi Fixpay untuk dioperasionalisasikan, mudah mengakses aplikasi, dan meningkatkan nilai kegunaan dari aplikasi Fixpay. Selanjutnya, untuk penelitian yang akan datang disarankan untuk menambahkan variabel bebas yang diduga mempengaruhi kepuasan pelanggan, dan memperluas sempel penelitian sehingga memperoleh data yang lebih besar.

\section{Referensi}

Akbar, Mohammad Muzahid dan Parvez, Noorjahan. (2009). the effects of customers' perceived service quality, trust, and customer satisfaction on customer loyalty. Journal Vol. 29, No. 1, pp.24-38

Anh, Chu Phuong. (2015). Factors Influence Customer Satisfaction In Mobile Commerce. Degree program in Business Administration International Business.

Chen, Loi Leong., Basit, Abdul., and Hassan, Zubair. (2017). The Impact Of Customer
Percieved Value On Customer Satisfaction: A Study On Malaysian Automobile Industry. International Journal of Accounting \& Business Management, Vol. 5 (No.1).

Chi, T., and Kilduff, P.P.D. (2011). Understanding consumer perceived value of casual sportswear: An empirical study. Journal of Retailing and Consumer Services, 18(5), 422-429.

Cooper, D.R., \& Schindler, P.S. (2011). Business Research Methods. New York: McGraw-Hill.

Fornell, C. (1992), "A national customer satisfaction barometer: The Swedish experience." Journal of Marketing, Vol. 56, pp. 6-21.

Ghozali, Imam. (2013). Aplikasi Analisis Multivariate dengan Program IBM SPSS 21 Update PLS Regresi. Semarang: Badan Penerbit Universitas Diponegoro

Grace, Diana., dan Novander, Novander. (2017). Analisis Pengaruh Automac Teller Machine dan Short Message Service Banking Terhadap Kepuasan Nasabah. Jurnal Elekronik Sistem Informasi dan Komputer Sekolah Tinggi IImu Informatika dan Komputer (JESIK), Vol. 3, No.1.

Lam, Shun Yin. Venkatesh Shankar, M. Lau, G. \& Lee, S. (1999). "Consumers' trust in a brand and link to brand loyalty". Journal of Market Focused Management, 4, 34170.

Lin, J., Wang, B., Wang, N. \& Lu, Y. (2014). Understanding the evolution of consumer trust in mobile commerce: a longitudinal study. Information Technology and Management, vol. 15, no. 1, pp. 37-49.

Lupiyoadi, Rambat. (2014). Manajemen Pemasaran Jasa, Berbasis Kompetensi. Jakarta: SalembaEmpat.

Mahaputra, M. Rizky. (2017). The Influence of Trust and Customer Value to Customer Satisfaction on Bank BRI Branch Soetomo Jambi. Saudi Journal of Business and Management Studies, Vol. 2, Issue. 8.

Malhotra, N.K. (2007). Marketing Research: An Applied Orientation. New Jersey: Pearson Education, Inc.

Morgan, R. M. \& Hunt, S. D. (1994). "The commitment-trust theory of relationship Marketing". Journal of Marketing, 58 (July), 20-38.

Santouridis, Ilias. (2009). E-Service Quality and its Impact on Customer Satisfaction and Trust: An Empirical Study on Greek 
Customers of Internet Shops. International Conference on Enterprise Systems, Accounting and Logistics

Sarjono, Haryadi., dan Julianita, Winda. (2011). SPSS vs LISREL Sebuah Pengantar Aplikasi untuk Riset. Jakarta: Salemba Empat.

Sekaran, U. (2007). Research Methods for Business: A skill Building Approach, $\left(5^{\text {th }}\right.$ ed.). New York: John Wiley \& Sons.

Sembiring, Inka Janita., Suharyono., dan Kusumawati, Andriani. (2014). Pengaruh Kualitas Produk Dan Kualitas Pelayanan Terhadap Kepuasan Pelanggan Dalam Membentuk Loyalitas Pelanggan (Studi pada Pelanggan McDonald's MT.Haryono Malang). Jurnal Administrasi Bisnis, Vol. 15, No. 1.

Shams-Ur-Rehman, Shareef, A. And Ishaque, A. (2012). Role Of Trust And Commitment In Creating Profitable Relationship With Customers. Interdisciplinary Journal of Contemporary Research In Business, vol. 4, no. 1, pp. 606-615.

Sholiha, Eva Ummi Nikmatus., dan Salamah, Mutiah. (2015). Structural Equaltion Modeling-Partial Least Square untuk Pemodelan Derajat Kesehatan Kabpaten/Kota di Jawa Timur (Studi Kasus Data Indeks Pembangunan Kesehatan Masyarakat Jawa Timur 2013). Jurnal Sains dan Seni ITS, Vol. 4, No. 2.
Siregar. (2013). Metode Penelitian Kuantitatif dilengkapi dengan Perbandingan Perhitungan Manual dan SPSS. Jakarta: Kencana.

Sobihah, Mutia., Mohamad, Mahadzirah., and Ali, Nor Azman. (2015). Relationship Between E-Commerce Service Quality, Satisfaction, Trust, and Customer Loyalty in the Hotel Industry in the east Coast of Peninsular Malaysia. Full Paper Proceeding GTAR, Vol. 1, 429-440.

Tjiptono, F., \& Gregorius, C. (2014). Service, Quality \& Satisfaction (3th ed). Yogyakarta: Andi Offset.

Tjiptono, Fandy. (2014). Pemasaran Jasa. Yogyakarta: Andi

Tsai, Ming-Tien., Tsai, Chung-Lin., and Chang, Han-Chao. (2010). The Effect Of Customer Value, Customer Satisfaction, And Switching Costs On Customer Loy: An Empirical Study Of Hypermarkets In Taiwan. Social Behavior And Personality, Vol. 38(6), 729-740. 